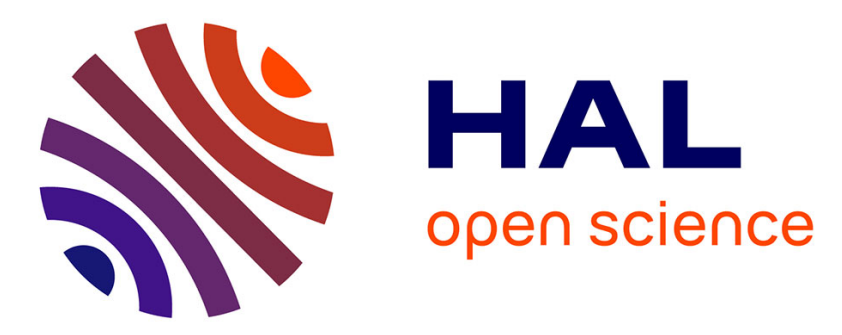

\title{
CLASSIFICATION OF RESEARCH AND APPLICATIONS OF THE COMPUTER AIDED PROCESS PLANNING IN MANUFACTURING SYSTEMS
}

Mohsen Soori, Mohammed Asmael

\section{To cite this version:}

Mohsen Soori, Mohammed Asmael. CLASSIFICATION OF RESEARCH AND APPLICATIONS OF THE COMPUTER AIDED PROCESS PLANNING IN MANUFACTURING SYSTEMS. Independent Journal of Management \& Production, 2020, 10.14807/ijmp.v12i5.1397 . hal-03024767

\section{HAL Id: hal-03024767 https://hal.science/hal-03024767}

Submitted on 26 Nov 2020

HAL is a multi-disciplinary open access archive for the deposit and dissemination of scientific research documents, whether they are published or not. The documents may come from teaching and research institutions in France or abroad, or from public or private research centers.
L'archive ouverte pluridisciplinaire HAL, est destinée au dépôt et à la diffusion de documents scientifiques de niveau recherche, publiés ou non, émanant des établissements d'enseignement et de recherche français ou étrangers, des laboratoires publics ou privés. 
INDEPENDENT JOURNAL OF MANAGEMENT \& PRODUCTION (IJM\&P)

http://www.ijmp.jor.br

v. 12, n. 5, July-August 2021

ISSN: 2236-269X

DOI: 10.14807/ijmp.v12i5.1397

\title{
CLASSIFICATION OF RESEARCH AND APPLICATIONS OF THE COMPUTER AIDED PROCESS PLANNING IN MANUFACTURING SYSTEMS
}

\author{
Mohsen Soori \\ Eastern Mediterranean University, Turkey \\ E-mail: mohsen.soori@emu.edu.tr \\ Mohammed Asmael \\ Eastern Mediterranean University, Turkey \\ E-mail: mohammed.asmael@emu.edu.tr
}

Submission: $7 / 28 / 2020$

Accept: 9/1/2020

\section{ABSTRACT}

The Computer Aided Process Planning (CAPP) systems are recently developed in manufacturing engineering to provide links between Computer Aided Design (CAD) and Computer Aided Manufacturing (CAM) systems. The CAPP systems are developed by considering the different issues of computer applications in production engineering. Optimization techniques can be applied to the CAPP to increase efficiency in part production processes. The energy consumption of part production process can be analyzed and optimized using the CAPP systems in order to increase added value in the part manufacturing process. Also, artificial neural networks as well as cloud manufacturing systems can be applied to the CAPP systems to share advantages of the different CAPP systems in different industry applications. Flexible process planning systems are developed using dynamic CAPP in order to cope with product varieties in process of part production. To develop potential energy saving strategies during product design and process planning stages, the advanced CAPP systems can be used. In this paper, a review of Computer Process Planning systems (CAPP) is presented and future research works are also suggested. It has been observed that the research filed can be moved forward by reviewing and analyzing recent achievements in the published papers.

Keywords: CAPP; CAD/CAM; Optimization; Efficiency of part production 
DOI: 10.14807/ijmp.v12i5.1397

\section{INTRODUCTION}

To develop process of part production, designing, manufacturing and assembly systems are considered to be modified. The link between the processes are Computer Aided Process Planning (CAPP) which deals with selection procedure of designing and manufacturing processes with the optimized conditions. The developed CAPP systems have a key role in the Computer Integrated Manufacturing (CIM) systems in order to develop the manufacturing engineering.

The major CAPP operations are related to the selection of suitable machine tool, machining operations, cutting tool and cost and time of part production. Available facilities as well as desired quality of the produced parts are the first functions of the CAPP operation. Then, the algorithm of CAPP will be applied to the manufacturing process in order to provide the optimized condition of part production regarding the desired quality of parts and facility limitations.

The first suggestion of using the computers in process planning operations is presented by Niebel (1967) in 1965. A critical review of recent developments and future trends in computer-aided process planning is presented by Xu et al. (2011). Current trend in computer aided process planning is presented by Ahmad et al. (2001) to classify the presented research works according to their focus.

A review in integration of process planning and scheduling is presented by Tan and Khoshnevis (2000) to discuss the extent of applicability of various approaches and suggest directions for future research. Survey on computer-aided process planning is presented by Yusof and Latif (2014) to classify the focused issues of research works in different areas. Review of computer-aided process planning systems for machining operation is presented by Isnaini and Shirase (2014) to discuss the effective parameters in development of CAPP systems for process planning of metal removal process.

A review on integrated process planning and scheduling systems is presented by Li et al. (2010) to classify the presented research works and suggest some future research trends. A review in agent technology for collaborative process planning is presented by Zhang and Xie (2007) to summarize the key issues in developing agent-based collaborative process planning systems including the applications of agent in scheduling, control, and enterprise integration and supply chain management.

A review of process planning techniques in layered manufacturing is presented by Kulkarni et al. (2000) to analyze the current situation and suggest future projections on the 
DOI: 10.14807/ijmp.v12i5.1397

possible directions of research in this area. Recent development on computer aided tissue engineering is reviewed by Sun and Lal (2002) to analyze and develop the utilization of computer-aided technologies in tissue engineering.

Assembly process planning and its future in collaborative manufacturing processes is analyzed and reviewed by Wang et al. (2009) to review and outline the methodologies and tools in optimal assembly plans and assembly lines. Integration of process planning and scheduling by considering non-linear approach, closed loop approach and distributed approach are discussed by Phanden et al. (2011) to increase efficiency in process of part manufacturing.

Also, application of CAD/CAM systems in developing the machining operations using virtual machining is presented by Soori et al. (2013; 2014; 2016; 2017). To increase accuracy as well as efficiency in process of part production using machining operations, virtual machining systems are developed in the research works.

There are two type of approached to the CAPP systems as variant approach and generative approach. Variant approach uses group technology that similar parts require similar plans and makes the necessary modifications to the plan for the new part. This approach needs a human operator to classify a part, input part information and the group technology plan to be implemented. In the generative approach, each parts are considered in order to generate the process plans without referring to existing plans.

New process plans by means of decision logic and process knowledge are generated in the CAPP systems. Semi-Generative macro-process planning for reconfigurable manufacturing is investigated by Azab et al. (2007) to increase efficiency in part production process using optimal solutions in terms of computation time of part manufacturing.

Sadaiah et al. (2002) presented the generative computer-aided process planning system for prismatic components in machining operations to apply CAPP to the machine tool set-up, machine tool selection, cutting tool selection, cutting parameter selection and generation of process plan sheet. A generative process planning system for cold extrusion is developed by Kumar et al. (2003) to obtain the optimal die design process parameters such as an upper bound model, an optimum die profile.

Pande and Kumar (2008) presented a generative process planning system for parts produced by rapid prototyping in order to generate intelligent slicing methodology by using the optimized process parameters. Development of a generative CAPP system for axisymmetric components for a job shop environment is presented by Kumar and Rajotia (2005) to provide relationship among various operations such as product design and product manufacturing using advanced CAPP. 
DOI: 10.14807/ijmp.v12i5.1397

In the present research work, different issues of research works in the Computer Aided Process Planning (CAPP) systems are categorized to provide a useful study for the researchers in the interesting field. As a result, new ideas in CAPP and gaps in the existing literature are obtained and future research works are also suggested in order to push forward this interesting research field.

Different kinds of generative process planning systems, Optimization techniques using the CAPP, artificial neural network in CAPP, artificial Intelligence in CAPP, Links between CAD/CAM and CAPP, Static and dynamic process planning systems, Feature-based and solid model based Process Planning systems, Variant Process Planning systems, Computer-Aided Inspection Planning systems, Energy efficient process planning systems, virtual machining systems for CAPP, applications of fuzzy environments to process planning systems, Knowledge based computer-aided process planning systems, Agent based computer-aided process planning systems, Multi-criteria decision making technique in the process planning systems, Additive subtractive hybrid manufacturing process planning systems and Process planning and scheduling in networked manufacturing systems are categorized as different issues of research works in CAPP.

Section 2 presents a review from research works related to CAPP. In the section 3, research works are classified according to the different topics in research to the CAPP and future research works in the CAPP systems are also suggested.

\section{REVIEW OF RESEARCH WORKS IN THE CAPP}

The research works in the field of CAPP is recently developed in different topics of computer applications in manufacturing engineering to increase quality as well as efficiency in the part production. Several approaches are recently developed in the generative CAPP systems. The different topics of research works are classified in this section in order to review their achievements in the research field.

\subsection{Optimization techniques using the CAPP}

In order to increase efficiency in process of part production, optimization techniques can be applied to the CAPP process. So, time and cost of accurate production can be decrease using the optimized parameters of part manufacturing. Application of genetic algorithm to optimized computer-aided process planning in distributed manufacturing environments is presented by Li et al. (2005). 
DOI: 10.14807/ijmp.v12i5.1397

Application of genetic algorithm to computer-aided process planning in preliminary and detailed planning is developed by Salehi and Tavakkoli-Moghaddam (2009). Chu et al. (2000) presented a novel methodology for optimized computer-aided process planning to develop a new approach for increasing the efficiency and quality of process planning, and for fully supporting concurrent engineering.

Optimization of operation sequencing in CAPP using simulated annealing technique is developed by Nallakumarasamy et al. (2011) to minimize the sum of machine tool working time , setup and tool change costs by using optimized machining parameters. To reduce the optimal cost with a lesser computational time along with generation of more alternate optimal feasible sequences, optimization of operation sequencing in CAPP using superhybrid genetic algorithms-simulated annealing technique is developed by Nallakumarasamy et al. (2011).

Process planning optimization for the manufacture of injection molding using a genetic algorithm is presented by Alam et al. (2003) to minimize overall processing time of part production. A CAPP framework with optimized process parameters for rotational components is presented by Sankar et al. (2008) to decrease time and cost of machining operations. Optimization of operations sequence in CAPP using an ant colony algorithm is presented by Krishna and Rao (2006) to increase efficiency in part production process.

\subsection{Artificial neural networks in CAPP}

To increase flexibility and capabilities in the CAPP systems, artificial neural networks can be applied. Thus, a new feature-based intelligent CAPP system can be generated in order to develop the process of part production.

Process and production planning in a cloud manufacturing environment is presented by $\mathrm{Lu}$ and $\mathrm{Xu}$ (2015) in order to develop the advanced CAPP using flexible production systems. Technological process planning by the use of neural networks is developed by Rojek (2017) to present advanced CAPP system that functions similarly to a human expert in the field in question.

As a result, the usefulness of neural networks and their high effectiveness in supporting the design of technological processes and CAPP systems are presented in the study. A neural network based methodology for machining operations selection in Computer-Aided Process Planning for rotationally symmetrical parts is presented by Deb et al. (2006) to develop the applications of artificial neural networks in CAPP. 
DOI: 10.14807/ijmp.v12i5.1397

Manufacturing knowledge modeling based on artificial neural network for intelligent CAPP is investigated by Wang et al. (2012) to develop intelligent CAPP system by using multiknowledge database. An intelligent process planning system for prismatic parts using STEP features is developed by Amaitik and Engin Kiliç (2007) to suggest a new feature-based intelligent CAPP system for avoiding complex feature recognition and knowledge acquisition problems. Artificial neural networks is developed by Yahia et al. (2002) to manufacture prismatic features using advanced CAPP systems. Intelligent tool path generation for milling of free surfaces using neural networks is presented by Balic and Korosec (2002) to increase machined surface quality in milling operations.

\subsection{Artificial Intelligence in CAPP}

Artificial Intelligence is an advanced tool in increasing the capabilities of the CAPP systems in order to minimize the cost of accurate products. To increase abilities of the CAPP systems, an intelligent computer program can be applied by using advanced knowledge and inference procedures in the CAPP applications.

An integrated artificial intelligent computer-aided process planning system is developed by Chang and Chang (2000) to perform the dynamic recognition and adaptivelearning tasks of the workpieces and process plans. The application of multi-agent systems for STEP-NC computer aided process planning of prismatic components is developed by Nassehi et al. (2006).

This paper examines the application of distributed artificial intelligence methods, namely collaborative multi-agent systems in designing an object-oriented process planning system for prismatic components in a STEP-NC compliant environment. Application of knowledge-based artificial immune system is presented by Prakash et al. (2012) to minimize the cost of the finished product.

Review on artificial intelligence systems application in process planning and manufacturing is presented by Kumar et al. (2017) to analyze the applications of artificial intelligence systems in terms of feature based modeling, standards for exchange of product model data approach, scheduling and manufacturing. Computational intelligence in computer aided process planning is presented by Stryczek et al. (2007) to obtain machining condition optimization, operation sequencing, machine tool setup and machine tool selection, and modeling in the EDM processes.

\subsection{Links between CAD/CAM and CAPP}


The CAD/CAM systems can be linked to the CAPP systems in order to generate advanced process plans by decreasing the time and cost of process analysis. Chen et al. (2012) developed computer-aided process planning for NC tool path generation of complex shoe molds. The automation of auxiliary boundary curve generation and machining strategies are considered in the study in order to present an advanced CAPP system.

Development of a simple and affordable computer aided process planning (CAPP) is presented by Abdul Karim and Tiong (2019). Manufacturing databases such as cutting tools databases, material databases and drawing databases are considered in the study to present the sequence of operations and work centers required to produce the product and its components. Manafi et al. (2017) presented the manufacturing information of machining features for computer-aided process planning systems.

Different machining features are analyzed and categorized in order to develop automation in attributing tolerances of machining features and identifying the reference faces. A case-based computer-aided process-planning system for machining operations of prismatic components is investigated by Tiwari et al. (2001). Automatic tool path generation of a featurebased CAD/CAPP/CAM integrated system is presented by Hou and Faddis (2006) to generate machining geometry information from CAPP to CAM systems. A feasible approach to the integration of CAD and CAPP is presented by Zhou et al. (2007) to increase the abilities of the CAPP systems by generating the automatic process drawing marking and 3D material stock CAD models.

\subsection{Static and dynamic process planning systems}

A modified genetic algorithm-based approach is developed by Shao et al. (2009) to facilitate the integration and optimization of the process planning and scheduling functions. The effect of dynamic and static dispatching strategies on dynamically planned flexible manufacturing systems is investigated by Abou-Ali and Shouman (2004) to analyze the modification process of dispatching strategies in flexible manufacturing systems.

Dynamic shopfloor scheduling in multi-agent manufacturing systems is presented by Wong et al. (2006) to provide integrated process plan and job shop scheduling solutions with a better global performance. Integrating flexible process plans with scheduling in flexible manufacturing systems is presented by Saygin and Kilic (1999) to decrease the gap between process planning and production scheduling. 
DOI: 10.14807/ijmp.v12i5.1397

Agent-based distributed manufacturing process planning and scheduling is developed by Shen et al. (2006) to generate more realistic and effective plans using dynamic process planning systems. Research on dynamic process planning system considering decision about machines based on neural networks is presented by Wang et al. (2004) to increase the CAPP systems capabilities in job-shop scheduling applications. Adaptive and dynamic process planning using neural networks is investigated by Joo et al. (2001) to increase flexibility and efficiency in unexpected situations of part manufacturing processes.

\subsection{Feature-based and solid model based process planning systems}

In the feature-based process planning system, feature recognition system is used to identify part feature and their attributes from the CAD file. But, in the solid model-based process planning, solid modeling package is used in order to design a 3D part. An intelligent feature-based process planning system for prismatic parts is presented by Patil et al. (2002) to develop an integrated part-process environment that enables quick turnaround from design to manufacture.

A feature-based inspection process planning system for co-ordinate measuring machine (CMM) is developed by Zhang et al. (2000) to generate an inspection process planning for a CMM machines in different industries. To increase efficiency in part manufacturing process, an innovative retrieval architecture to acquire similar mechanical artifacts based on the local feature correspondence is developed by You and Tsai (2010).

To simulate the stations, operations, and their inter-relations in bending operations for progressive die design, integrated feature-based modelling and process planning is developed by Cheok and Nee (2002). Feature-based representation for manufacturing planning is developed by Case and Harun (2000) to create a design tool for mechanical assembly systems in terms of features analysis and modification for advanced manufacturing systems. An integrated web-based CAD/CAPP/CAM system is developed by Álvares et al. (2008) to increase CAPP system in analysis of the remote design and manufacture of feature-based cylindrical parts.

\subsection{Variant process planning systems}

Template-based variant process planning for manned assembly lines is investigated by Ham et al. (2017) to generate a standard process plan and for the development of a new process plan based on standard ones. Variant process planning for manned assembly lines is shown in the figure 1 Ham et al. (2017). 
DOI: 10.14807/ijmp.v12i5.1397

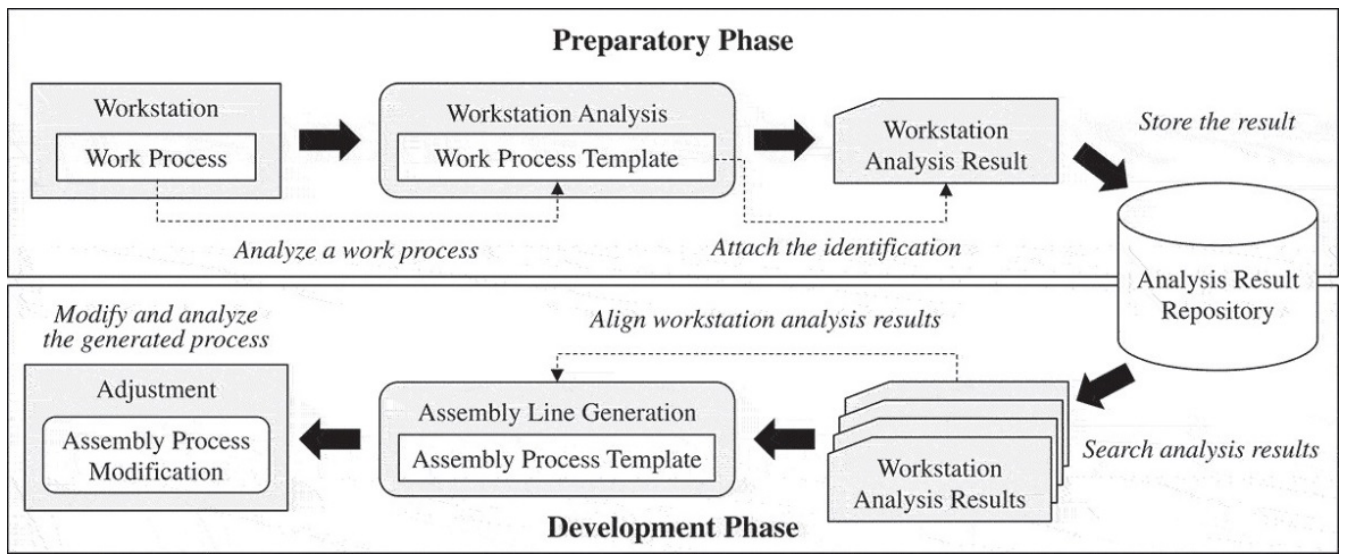

Figure 1: Variant process planning for manned assembly lines Source: Ham et al. (2017).

Variant process planning of casting model using AHP-based nearest neighbor algorithm is developed by Chougule and Ravi (2005) to modify the process parameter such as size, shape complexity, section thickness for the geometry and surface finish, tolerance, maximum void size for quality of produced parts using casting operations.

Design classification and hybrid variant-generative process planning is presented by Nau et al. (2000) to select processes and a variant fixture planning procedure for indexing mechanical designs and estimating manufacturing cycle time during product design. Wang et al. (2005) presented the complex assembly variant design in agile manufacturing systems in order to develop the applications of the CAPP in part production. Some aspects of variant computer aided process planning systems is presented by Przybysz and Pijanowski (2007) to modify the CAPP applications in computer integrated manufacturing systems.

\subsection{Computer-aided inspection planning systems}

To increase accuracy in part production processes, Zhao et al. (2009) presented applications of CAPP systems in Coordinate Measuring Machines (CMMs). As a result, a new notion of integrating the machining and inspection process planning based on the STEP-NC is developed in the study.

A computer-aided inspection planning system for on-machine measurement is developed by Lee et al. (2004) to develop the applications CAPP system in accuracy enhancement of the machining processes. The Local inspection planning systems are developed by Cho et al. (2004) to present a computer-aided inspection planning system for onmachine measurement. The fuzzy set theory, the Hammersley's algorithm and the TSP method are applied for the local inspection planning in order to develop a new local inspection planning strategy system. 
DOI: 10.14807/ijmp.v12i5.1397

Feature-based design approach for integrated CAD and computer-aided inspection planning for efficient measurement of CMMs is developed by Kamrani et al. (2015) to increase accuracy in process of part manufacturing. To develop more efficient measuring methodology for a CMM in complicated workpieces, a feature-based inspection planning system for CMM machines is developed by Cho et al. (2005).

Inspection Planning Strategy for the On-Machine Measurement Process Based on CAD/CAM/CAI Integration is developed by Cho and Seo (2002) to develop an effective inspection planning strategy for sculptured surfaces in the OMM (on-machine measurement) process. Inspection path generation in haptic virtual CMM is developed by Yang and Chen (2005) to the development of the proposed novel CMM off-line inspection path planning environment.

\subsection{Energy efficient process planning systems}

Energy efficient process planning for CNC machining is developed by Newman et al. [53] to validate the introduction of energy consumption in the objectives of process planning for CNC machining. Calefati et al. (2012) developed the energy efficient process planning system to provide developed production planning systems in metal formed or machined parts for automotive, aeronautic and domestic appliances.

To generate products with maximum value-added at minimum energy consumption, energy efficient process planning based on numerical simulations is presented by Neugebauer et al. (2011). Systematic literature review of decision support models for energy-efficient production planning is investigated by Biel and Glock (2016) to provide more energy-efficient production processes in terms of minimizing the energy consumption.

To integrate criteria of energy efficiency and effectiveness in manufacturing planning and scheduling systems in part production process, a methodology for planning and operating energy-efficient production systems is presented by Weinert et al. (2011). Energy efficiency performance in production management systems is developed by Bunse et al. (2011) to increase efficiency of energy consumption in production processes.

Energy management system is investigated by Müller et al. (2013) to develop new generation of factories with computer aided process planning of energy-efficient systems. To develop potential energy saving strategies during product design and process planning stages, unit process energy consumption models for material removal processes is investigated by Kara and Li (2011). 
DOI: 10.14807/ijmp.v12i5.1397

\subsection{Virtual machining systems for CAPP}

In order to evaluate the machining operation in the process planning stages, a virtual machining simulator is developed by Narita et al. (2000). NC codes simulator, geometric simulator and physical simulator are designed in the system to present optimal condition of machining process for process planners. Procedure of the virtual machining simulator is shown in the Figure 2 Narita et al. (2000).

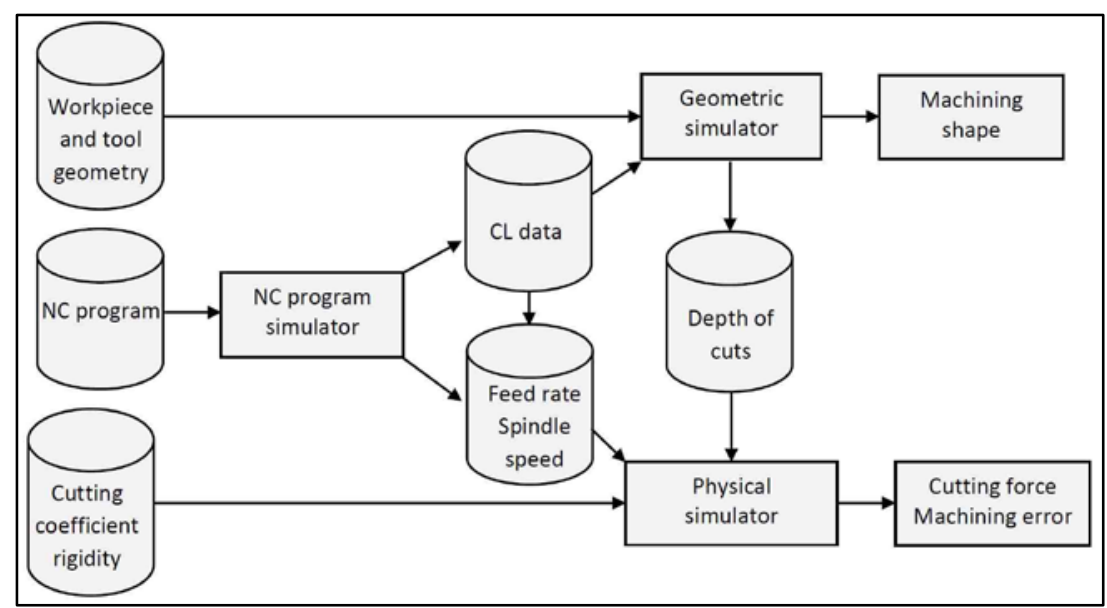

Figure 2: Procedure of the virtual machining simulator Source: Narita et al. (2000).

To meet desired geometric tolerances in milling operations, application of tool deflection knowledge in process planning using selecting optimal feed rates is presented by Ong and Hinds (2003). Also, application of virtual machining system in process planning of part manufacturing is presented by Sormaz et al. (2007).

The workpiece geometries, cutting tools and tolerances are considered in the system to generate machining strategies with regard to desired quality for produced parts. So, efficiency of part production can be increased using presented virtual machining system in the study. Moreover, application of virtual machining system in process planning is presented by Kim and Woo (2013) to determine the maximum cutter sizes in milling operations. In order to produce a feature in a shorter period of time, the system can detect virtual corners to calculate the maximum cutter sizes in machining paths.

The energy consumption of machine tools is simulated in virtual environments by Brecher et al. (2013) to increase energy efficiency aspects in process planning of part production. The presented virtual machining system in study can analyze and reduce required power of machine tools in order to increase efficiency of part manufacturing. Applications of 
DOI: 10.14807/ijmp.v12i5.1397

genetic algorithms in process planning of 2.5-axis pocket machining operations are presented by Ahmad et al. (2010).

A new virtual machining system is developed in the study to select optimal sequence of cutting tools in 2.5-axis pocket machining operations by considering given pocket geometry, a database for cutting tools, cutting parameters and tool holder geometry. Prediction of machining accuracy based on geometrical errors in five-axis peripheral milling operations is presented by Ding et al. (2014) in order to develop a process planning system in virtual environments.

\subsection{Applications of fuzzy environments to process planning systems}

Fuzzy-genetic approach to aggregate production-distribution planning in supply chain management is investigated by Aliev et al. (2007) to increase efficiency in part production process using CAPP systems. A fuzzy linear programming based approach for tactical supply chain planning in an uncertainty environment with multi-echelon, multi-product, multi-level, multi-period supply chain network is developed by Peidro et al. (2010) to achieve the best use of the available resources along the time horizon.

The effectiveness of a fuzzy mathematical programming approach for supply chain production planning with fuzzy demand is presented by Mula et al. (2010) to obtain more knowledge about the impact of fuzzy programming on supply chain planning problems with uncertain demands. Fuzzy optimization for supply chain planning under supply, demand and process uncertainties is developed by Peidro et al. (2009) to provide the decision maker with alternative decision plans for different degrees of satisfaction.

A causal analytical method for group decision-making under fuzzy environment is investigated by Lin and $\mathrm{Wu}$ (2008) to analyze the cause-effect relationship of complex problems in fuzzy environments. A robust optimization model for multi-site production planning problem in an uncertain environment is presented by Leung et al. (2007) to obtain optimal medium-term production strategy including the production loading plan and workforce level while considering different economic growth scenarios.

\subsection{Knowledge based computer-aided process planning systems}

Development of a computer-aided process planning system based on a knowledge base is investigated by Sasaki et al. (2003) to know-how of skilled designers as well as design practices, and allows the assembly sequence of hull parts and intermediate products to be defined automatically. 
DOI: 10.14807/ijmp.v12i5.1397

Knowledge Management in Process Planning is also studied by Denkena et al. (2007) to present an overview of the CAPP field and describes a holistic component manufacturing process planning model based on an integrated approach combining technological and business considerations. Knowledge capturing methodology in process planning is investigated by Park (2003) to apply to the process planning of hole making operations.

Object-oriented knowledge-based computer-aided process planning system for bare circuit boards manufacturing is investigated by Law et al. (2001) to develop the advantages of applying the knowledge objects approach in a computer-aided process planning systems. Object representation of the planning knowledge for manufacturing of printed circuit boards process planning is shown in the figure 3 Law et al. (2001).

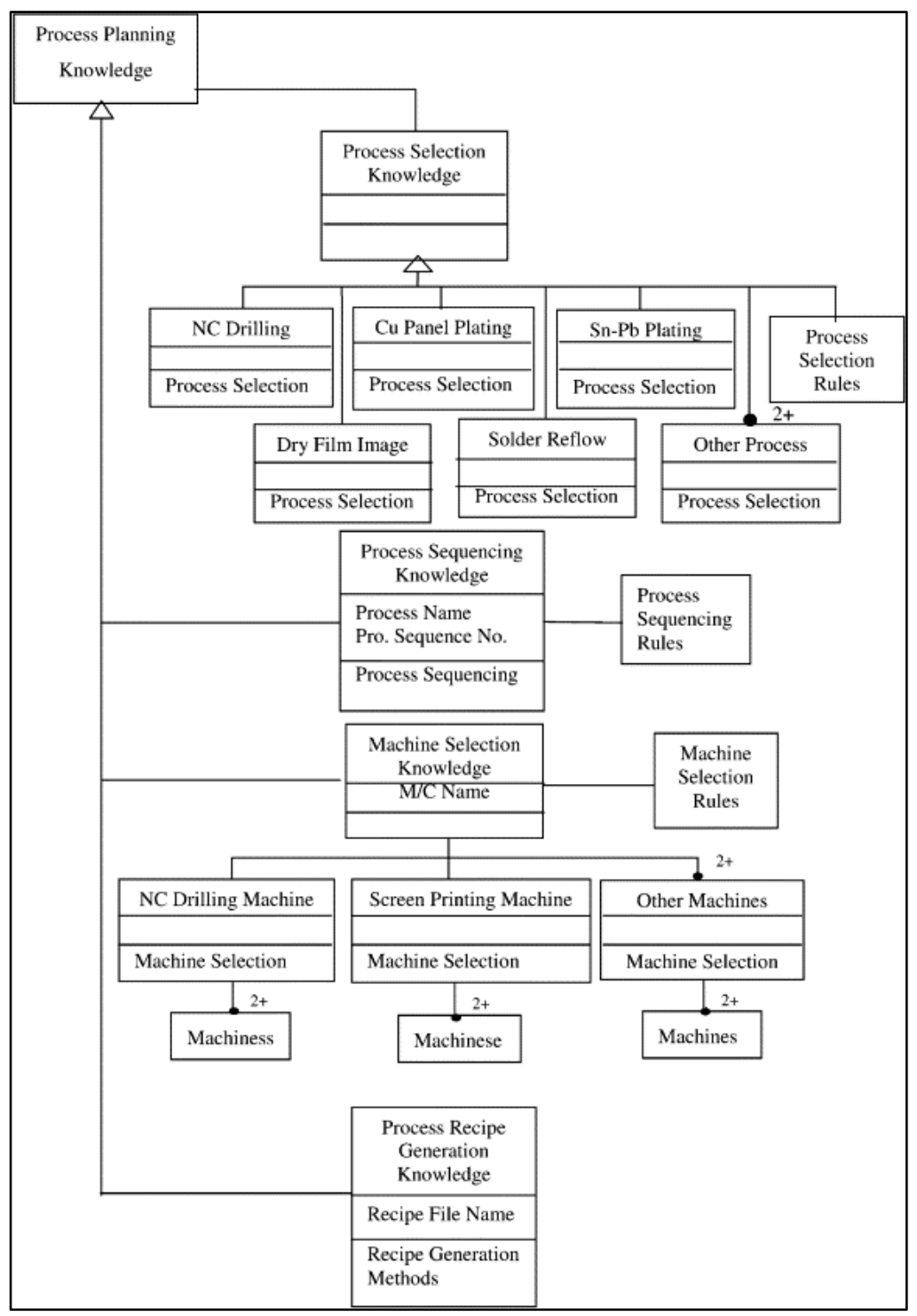

Figure 3: Object representation of the planning knowledge for manufacturing of printed circuit boards process planning

Source: Law et al. (2001). 
ISSN: 2236-269X

DOI: 10.14807/ijmp.v12i5.1397

Development of a generic computer-aided process planning support system is investigated by Yuen et al. (2003) to increase applications of CAPP systems in advanced manufacturing processes. A knowledge based CAPP system for automated design of deep drawing die for axisymmetric parts is presented by Naranje and Kumar (2014) to automate all major activities of design of deep drawing die such as manufacturability assessment of deep drawn parts, design of strip-layout, process planning, selection of die components and modeling of die components and die assembly. The sub-system AUTODDMOD is developed in the study for automatic modeling (2D and 3D) of deep drawing die components and die assembly in the drawing editor of AutoCAD software as is shown in the figure 4 Naranje and Kumar (2014).

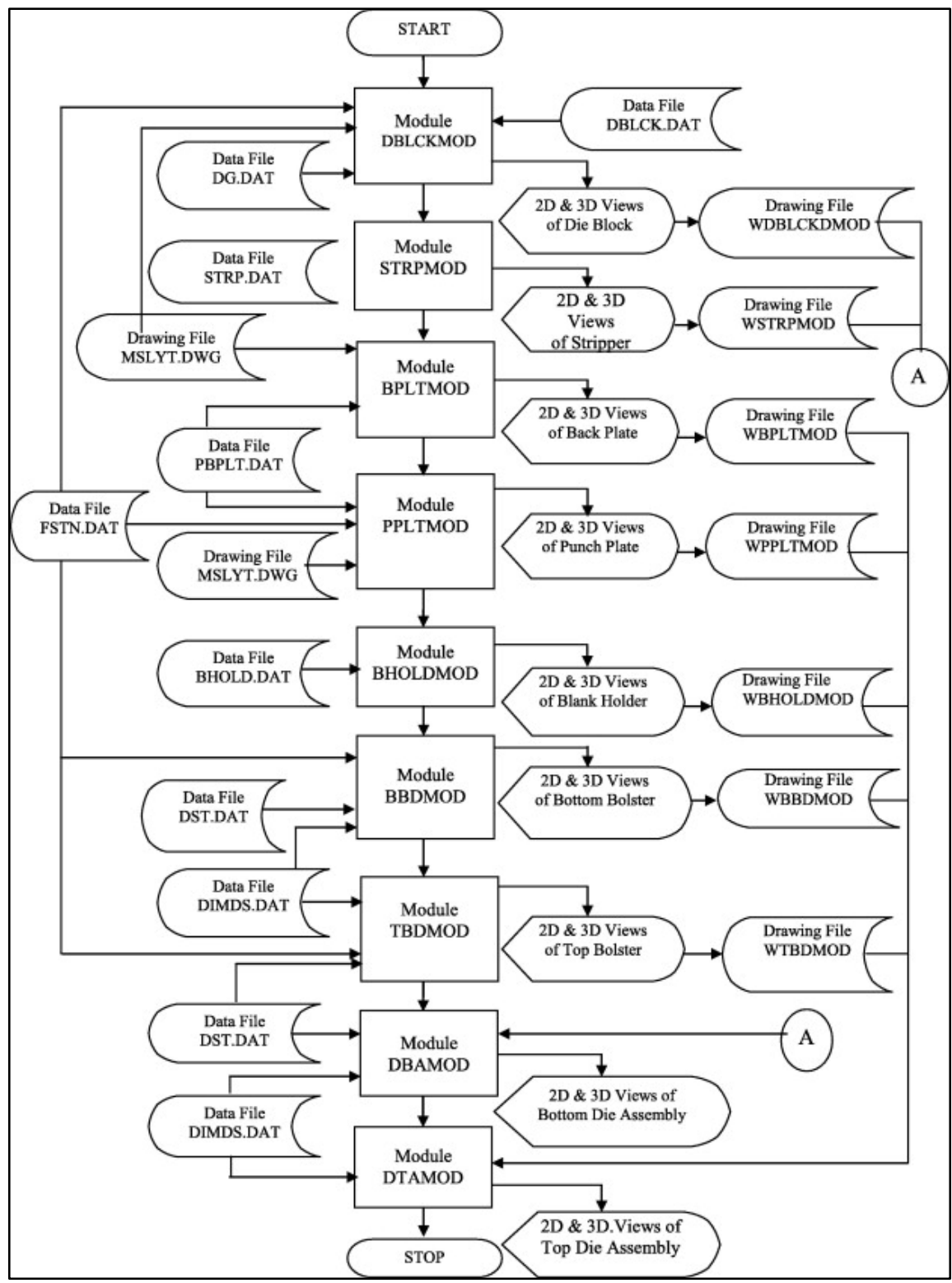

Figure 4: Execution of the sub-system AUTODDMOD Source: Naranje and Kumar (2014). 
DOI: 10.14807/ijmp.v12i5.1397

The hybrid method of knowledge representation in a CAPP knowledge based system is presented by Grabowik et al. (2012) to develop the applications of the CAPP systems in modern advanced production processes.

\subsection{Agent based computer-aided process planning systems}

The application of multi-agent systems for STEP-NC computer aided process planning of prismatic components is investigated by Nassehi et al. (2006) to increase capabilities of the CAPP systems in manufacturing systems. An agent-based approach for distributed process planning using multi-agent negotiation and cooperation is developed by Wang and Shen (2003) to increase applications of CAPP systems in the part production processes.

Multi-agent system for distributed computer-aided process planning problem in emanufacturing environment is investigated by Agrawal et al. (2009) to obtain the optimal/near optimal process plan with the help of available resources in the manufacturing systems. To generate process plans for discrete component manufacture, the application of STEP-NC using agent-based process planning is investigated by Allen et al. (2005).

Agent technology for collaborative process planning is reviewed by Zhang and Xie (2007) to develop the agent-based collaborative process planning systems. Manufacturing planning and predictive process model integration using software agents is developed by Feng et al. (2005) to integrate various manufacturing software applications in part production processes. Agent interaction diagram is developed and presented in this paper as shown in the figure 5 Feng et al. (2005).

To develop the applications of process planning for integrating design and shop floor scheduling systems, modelling of integrated, distributed and cooperative process planning system using an agent-based approach is presented by Chan et al. (2001). An agent-oriented approach to resolve scheduling optimization in intelligent manufacturing is developed by Guo and Zhang (2010) to develop a multi-agent-based scheduling system for intelligent manufacturing systems. An agent-based approach for integrated process planning and scheduling system is presented by $\mathrm{Li}$ et al. (2010) to manage the interactions and communications between agents in developed CAPP systems. Agent-based distributed manufacturing process planning and scheduling is reviewed by Shen et al. (2006) to discuss major issues in these research areas are, and identify future research opportunities and challenges of the advanced CAPP systems. 
DOI: 10.14807/ijmp.v12i5.1397

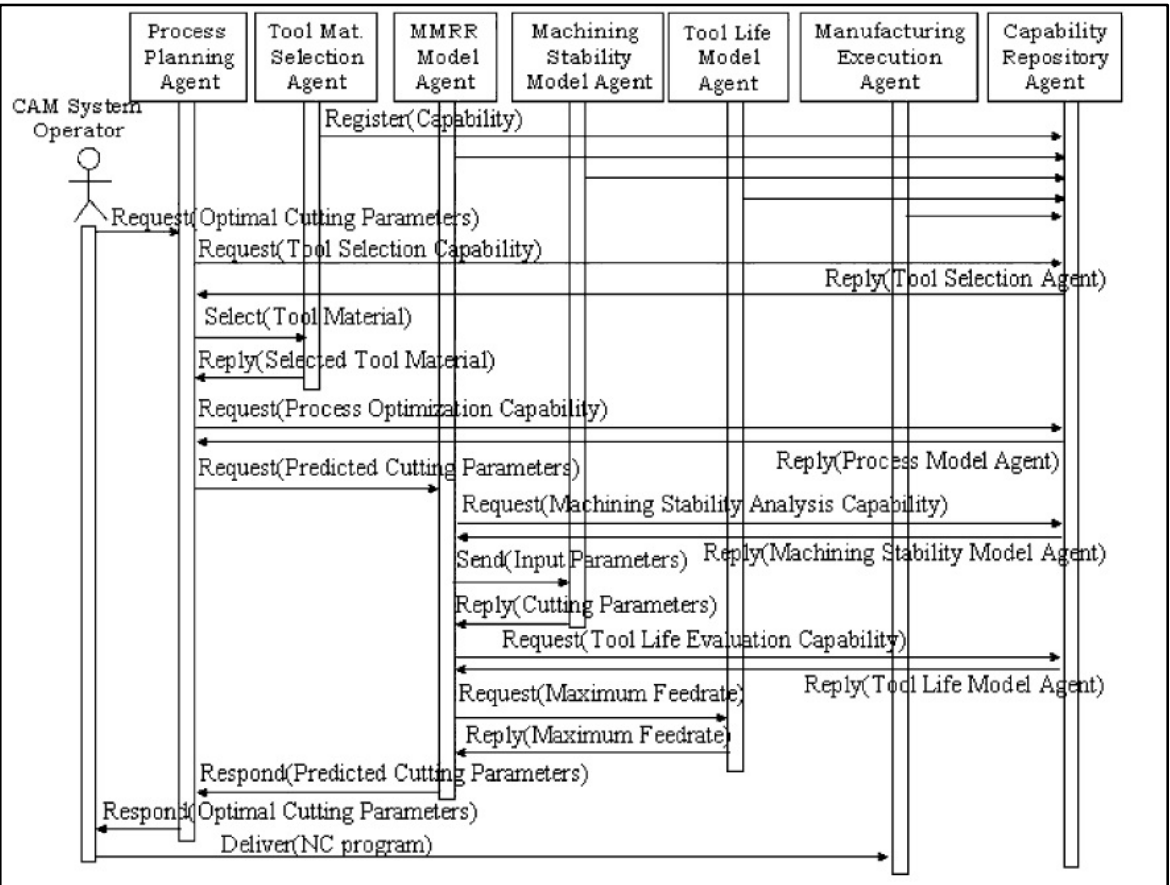

Figure 5: Agent interaction diagram for the advanced CAPP systems Source: Feng et al. (2005).

\subsection{Multi-criteria decision making technique in the process planning systems}

Ontology based personalized route planning system using a multi-criteria decision making approach is presented by Niaraki and Kim (2009) to develop new graph algorithms based on semantic web technology. Application of multi-criteria decision making to sustainable energy planning systems is reviewed by Pohekar and Ramachandran (2004) to tackle uncertainties in the decision making for the process planning strategies.

Material and manufacturing process selection for additive manufacturing using multicriteria decision making is investigated by Zaman et al. (2018) to for integrated design in additive manufacturing processes. The Analytical Hierarchy as multi-criteria decision making is applied to material process selection in the additive manufacturing processes as is shown in the figure 6 Zaman et al. (2018). 


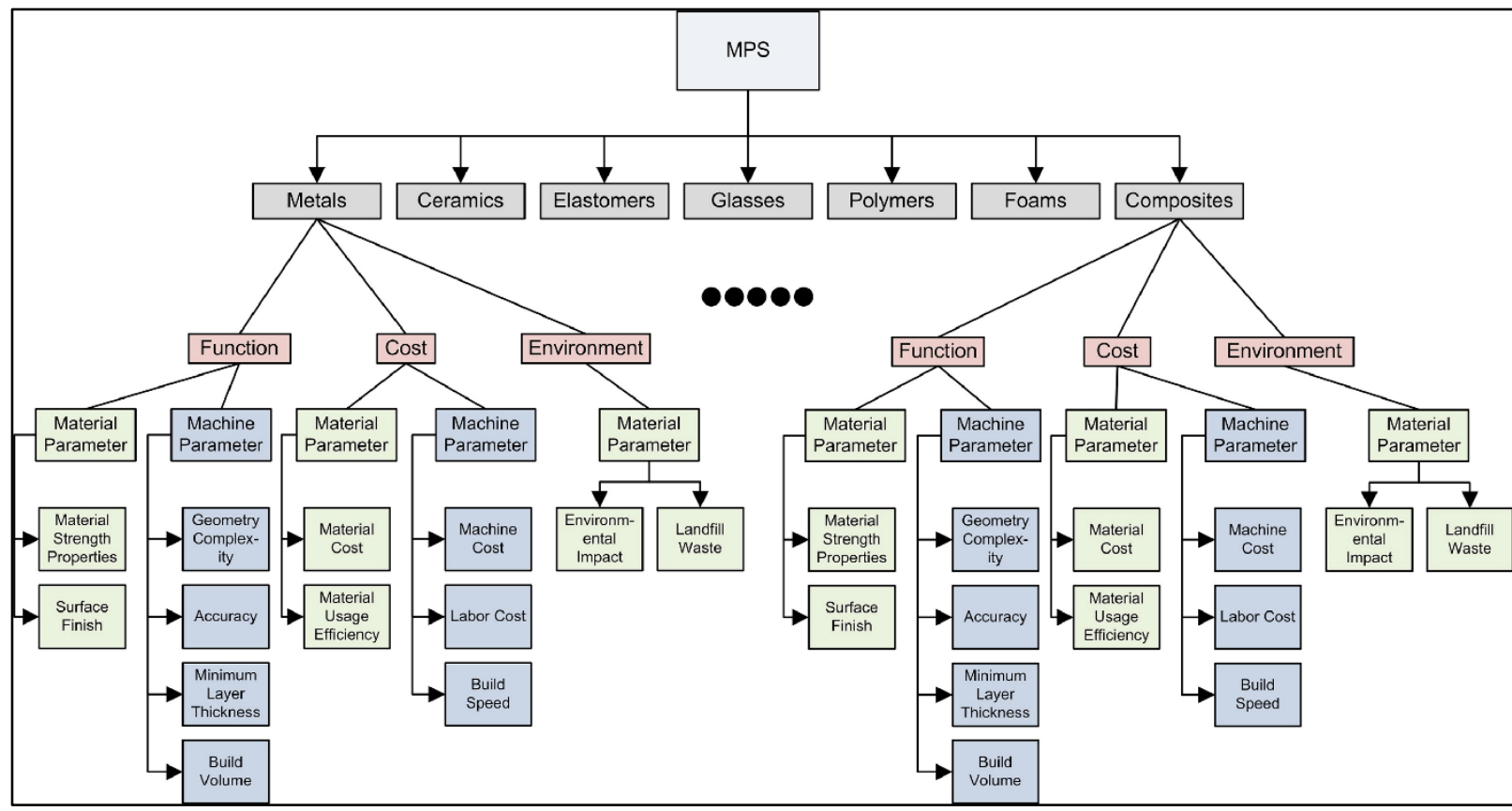

Figure 6: The Analytical Hierarchy decision structure Source: Zaman et al. (2018).

Multi-criteria selection of manufacturing processes in the conceptual process planning is presented by Lukic et al. (2017) to rank and create process planning according to the evaluation and ranking of manufacturing cycle time, process flexibility, material utilization, quality and operating costs.

\subsection{Additive subtractive hybrid manufacturing process planning systems}

Process planning for additive and subtractive manufacturing technologies is presented by Newman et al. (2015) in order to enable the strengths of additive and subtractive technologies to be combined with the inspection process. Operational structure of the Re-Plan process planning system is shown in the figure 7 Newman et al. (2015).

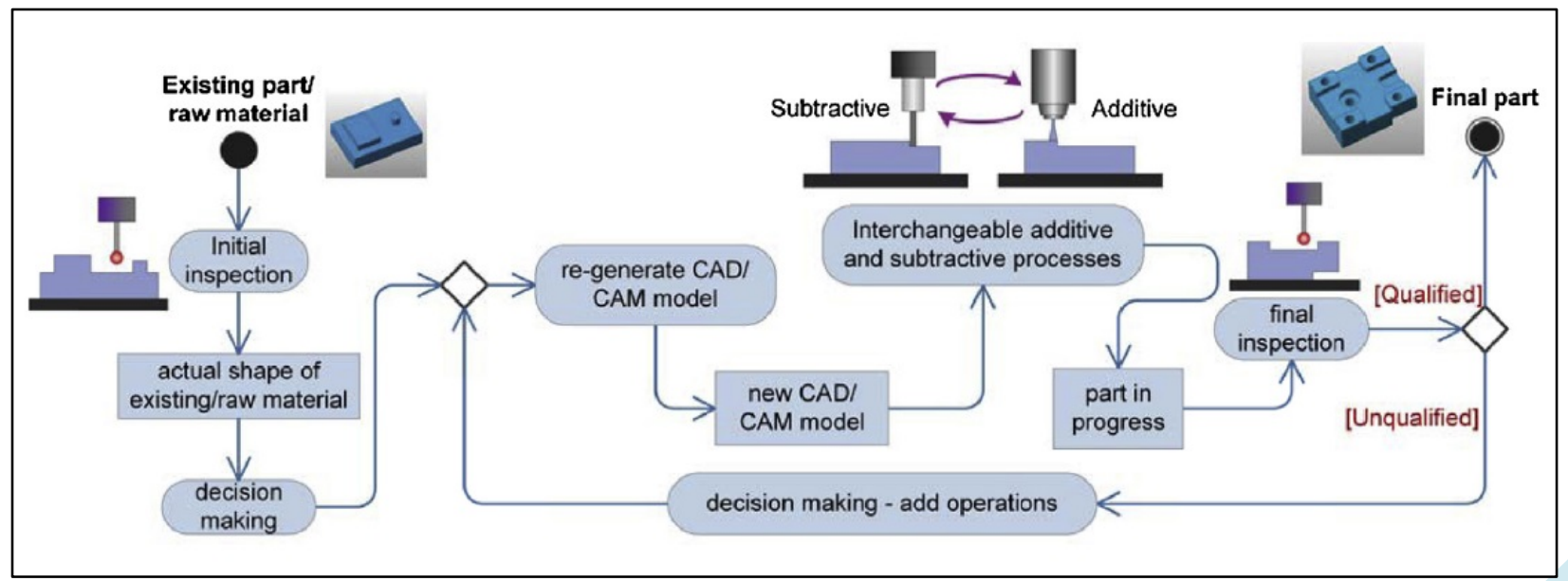

Figure 7: Operational structure of the Re-Plan process planning system Source: Newman et al. (2015). 
DOI: 10.14807/ijmp.v12i5.1397

Process planning for combined additive and subtractive manufacturing technologies in a remanufacturing context is investigated by Paris and Mandil (2017) to reuse existing parts directly to produce new parts (or final parts) in order to avoid the material recycling stage. The developed methodology for the design of additive manufacturing and machining process sequence is shown in the figure 8 Paris and Mandil (2017).

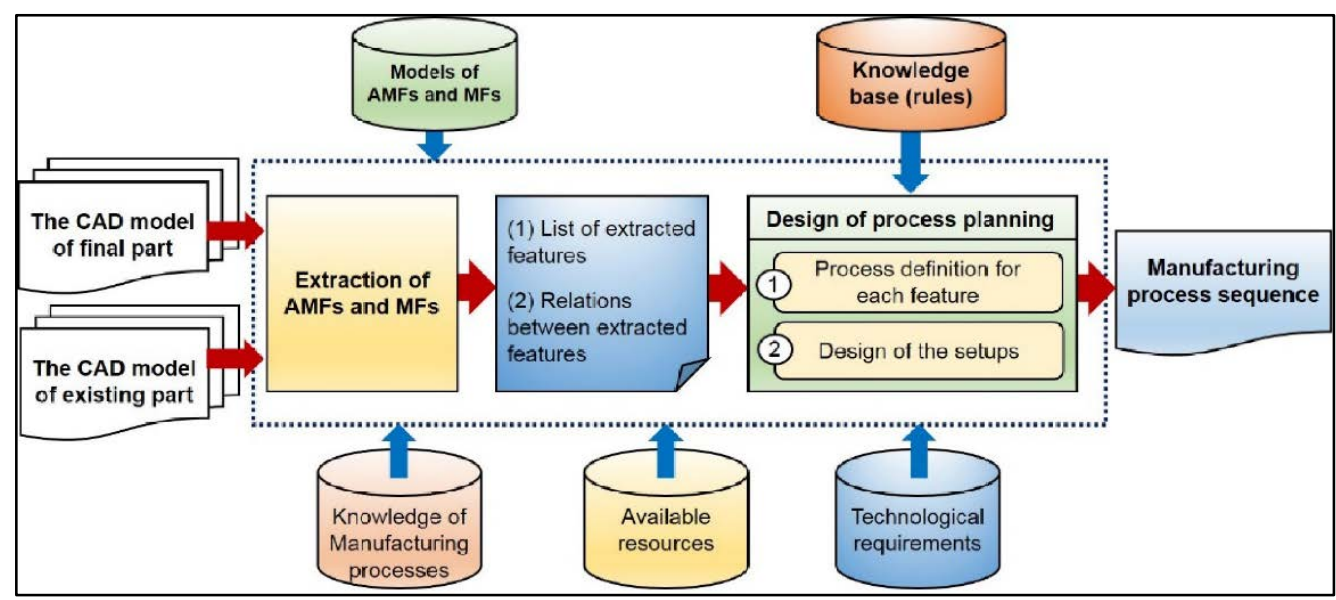

Figure 8: The developed methodology for the design of additive manufacturing and machining process sequence Source: Paris and Mandil (2017).

A novel process planning approach for hybrid manufacturing consisting of additive, subtractive and inspection processes is presented by Zhu et al. (2012) to effectively utilize manufacturing resources for hybrid processes. Development of a modular computer-aided process planning (CAPP) system for additive-subtractive hybrid manufacturing of pockets, holes, and flat surfaces is presented by Basinger et al. (2018) to decrease the machining time in part production processes.

\subsection{Process planning and scheduling in networked manufacturing systems}

Machine availability monitoring and machining process planning using cloud manufacturing systems is presented by Wang et al. (2013) to share manufacturing resources as services with lower support and maintenance. The process of information enrichment from machining features to function blocks together with their relationship is shown in figure 9 Wang et al. (2013). 
DOI: 10.14807/ijmp.v12i5.1397

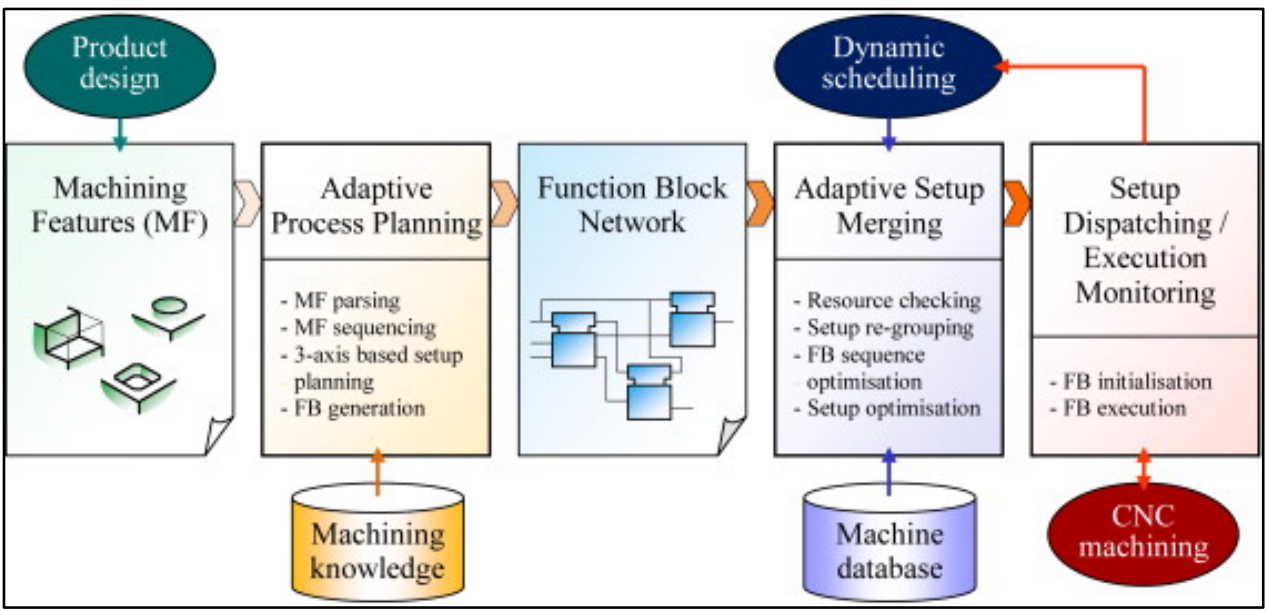

Figure 9: Information evolution from machining features to function blocks Source: Wang et al. (2013).

Integration of process planning and scheduling using mobile-agent based approach in a networked manufacturing environment is presented by Manupati et al. (2016) to develop the capabilities of the CAPP systems by connecting via networks. A new paradigm in digital manufacturing and design innovation using the cloud based design and manufacturing is presented by $\mathrm{Wu}$ et al. (2015) to develop the process of decision making in the advanced manufacturing systems. Cloud-based design and manufacturing for the example of smart delivery drone is shown in the figure $10 \mathrm{Wu}$ et al. (2015).

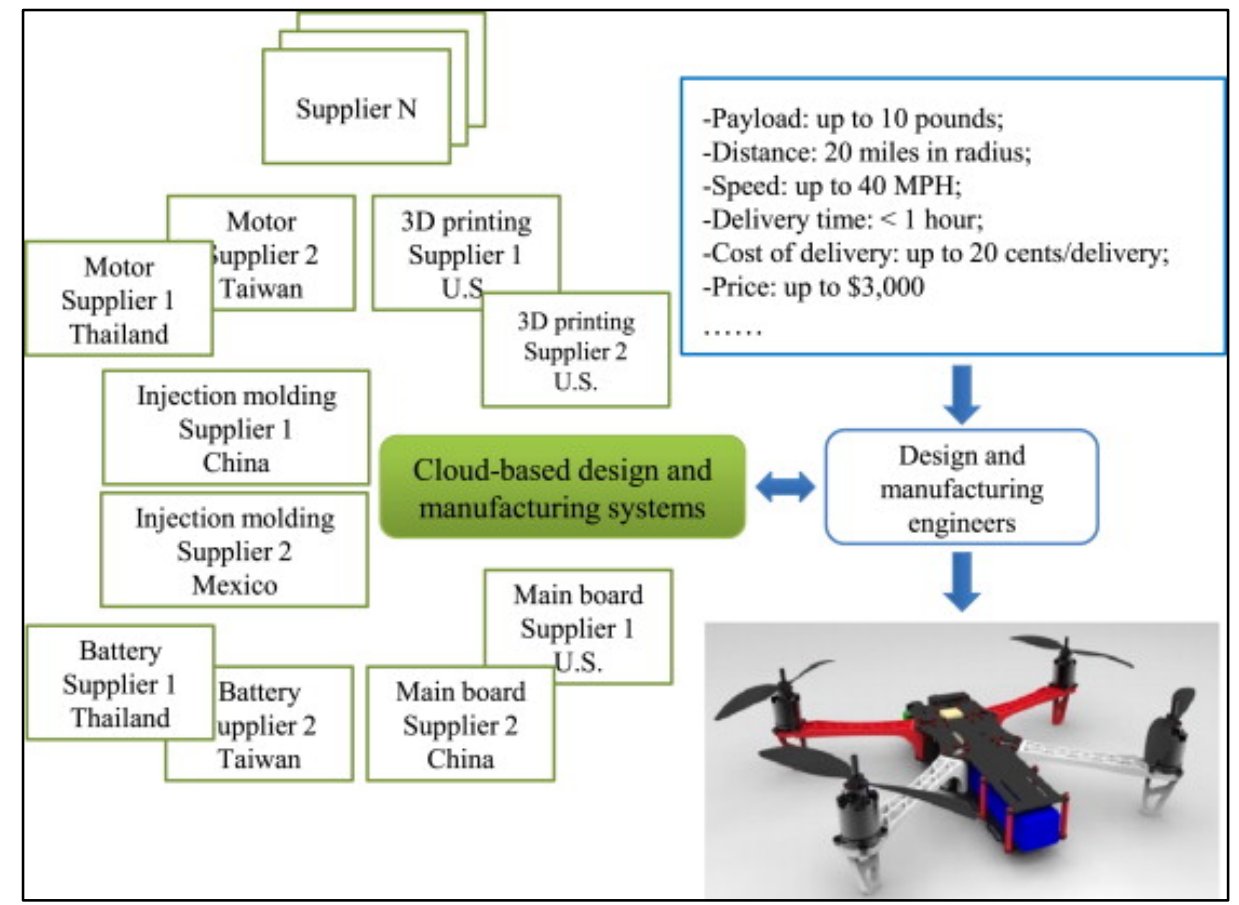

Figure 10: Cloud-based design and manufacturing for the example of smart delivery drone Source: Wu et al. (2015).

To develop the CAPP/CAM models using networked manufacturing systems in the part production process, CAPP model for prismatic parts in digital manufacturing is presented by 
INDEPENDENT JOURNAL OF MANAGEMENT \& PRODUCTION (IJM\&P)

http://www.ijmp.jor.br

v. 12, n. 5, July-August 2021

ISSN: 2236-269X

DOI: 10.14807/ijmp.v12i5.1397

Majstorović et al. (2013). A framework of STEP-NC manufacturing system using networked manufacturing systems is presented by Han et al. (2012) to integrate CAD, CAPP, CAM and CNC machining operations.

Recent developments of the CAPP systems in manufacturing engineering is presented in the Table 1.

Table 1: Topic of research Work

\begin{tabular}{|c|c|c|}
\hline Topic of research work & Papers & Finding/ Discoveries \\
\hline \multirow{3}{*}{$\begin{array}{l}\text { Optimization techniques } \\
\text { using the CAPP }\end{array}$} & $\begin{array}{c}\text { Salehi and } \\
\text { Tavakkoli- } \\
\text { Moghaddam (2009) } \\
\end{array}$ & $\begin{array}{l}\text { Machine tools, cutting tools and tool access direction } \\
\text { are optimized by using the genetic algorithm. }\end{array}$ \\
\hline & $\begin{array}{l}\text { Nallakumarasamy } \\
\text { et al. (2011) }\end{array}$ & $\begin{array}{c}\text { Simulated annealing technique is developed to } \\
\text { obtain optimal sequences in a single run with lesser } \\
\text { computational time. }\end{array}$ \\
\hline & $\begin{array}{l}\text { Siva Sankar et al. } \\
\qquad(2008)\end{array}$ & $\begin{array}{l}\text { Optimized process parameters for rotational } \\
\text { components are obtained to which lead to reduce } \\
\text { machining time and cost as compared to handbook } \\
\text { readings and traditional practices. }\end{array}$ \\
\hline \multirow{3}{*}{$\begin{array}{l}\text { Artificial neural networks in } \\
\text { CAPP }\end{array}$} & Rojek (2017) & $\begin{array}{l}\text { The use of neural network models in CAPP are } \\
\text { developed to aid CAPP for complex real systems. }\end{array}$ \\
\hline & $\begin{array}{l}\text { Wang, Zhang, and } \\
\text { Su (2012) }\end{array}$ & $\begin{array}{l}\text { Intelligent CAPP system using the neural networks } \\
\text { are developed to increase capabilities of CAPP } \\
\text { systems. }\end{array}$ \\
\hline & Yahia et al. (2002) & $\begin{array}{l}\text { To manufacture prismatic features, powerful and } \\
\text { flexible CAPP systems are introduced using the } \\
\text { neural networks. }\end{array}$ \\
\hline \multirow{3}{*}{$\begin{array}{l}\text { Artificial Intelligence in } \\
\text { CAPP }\end{array}$} & $\begin{array}{l}\text { Chang and Chang } \\
\text { (2000) }\end{array}$ & $\begin{array}{c}\text { To generating multiple process plans using an } \\
\text { integrated artificial intelligent, fuzzy logic rules are } \\
\text { applied. }\end{array}$ \\
\hline & $\begin{array}{l}\text { Prakash, Chan, and } \\
\text { Deshmukh (2012) }\end{array}$ & $\begin{array}{l}\text { A mathematical model is developed to analyze the } \\
\text { Randomized CIM environment using advanced } \\
\text { CAPP systems. }\end{array}$ \\
\hline & Stryczek (2007) & $\begin{array}{c}\text { Elements of a typical CAPP system such as FBM, } \\
\text { part feature extraction and integration, process } \\
\text { planning system development are considered to } \\
\text { develop the CAPP systems. }\end{array}$ \\
\hline \multirow{3}{*}{$\begin{array}{c}\text { Links between CAD/CAM } \\
\text { and CAPP }\end{array}$} & $\begin{array}{l}\text { Manafi, Nategh, } \\
\text { and Parvaz (2017) }\end{array}$ & $\begin{array}{l}\text { The extraction of manufacturing information of } \\
\text { prismatic workpieces from CAD output usable in } \\
\text { CAPP systems are investigated in the study. }\end{array}$ \\
\hline & $\begin{array}{l}\text { Tiwari, Kotaiah, } \\
\text { and Bhatnagar } \\
(2001)\end{array}$ & $\begin{array}{l}\text { Machining operations of prismatic components are } \\
\text { analyzed and modified to develop the process plans } \\
\text { in dynamic shop-floor situations. }\end{array}$ \\
\hline & Zhou et al. (2007) & $\begin{array}{l}\text { A practical approach to a total integration of CAD } \\
\text { and CAPP based on commercial systems are } \\
\text { developed. }\end{array}$ \\
\hline \multirow{2}{*}{$\begin{array}{l}\text { Static and dynamic process } \\
\text { planning systems }\end{array}$} & Shao et al. (2009) & $\begin{array}{l}\text { A new integration model with a modified GA-based } \\
\text { approach are developed to facilitate the integration } \\
\text { and optimization of CAPP systems. }\end{array}$ \\
\hline & Wong et al. (2006) & $\begin{array}{l}\text { A hybrid contract net protocol for the dynamic } \\
\text { integration of process planning and scheduling } \\
\text { problems is presented. }\end{array}$ \\
\hline
\end{tabular}


INDEPENDENT JOURNAL OF MANAGEMENT \& PRODUCTION (IJM\&P)

http://www.ijmp.jor.br

v. 12, n. 5, July-August 2021

ISSN: 2236-269X

DOI: 10.14807/ijmp.v12i5.1397

\begin{tabular}{|c|c|c|}
\hline & $\begin{array}{l}\text { Shen, Wang, and } \\
\text { Hao (2006) }\end{array}$ & $\begin{array}{l}\text { Applications of agent-based approaches in } \\
\text { distributed manufacturing process-planning and } \\
\text { scheduling systems are presented. }\end{array}$ \\
\hline \multirow{3}{*}{$\begin{array}{l}\text { Feature-based and solid } \\
\text { model based Process } \\
\text { Planning systems }\end{array}$} & $\begin{array}{l}\text { Patil and Pande } \\
\text { (2002) }\end{array}$ & $\begin{array}{l}\text { Advantages of the Intelligent Feature-based Process } \\
\text { Planning to provide advanced manufacturing } \\
\text { systems are presented. }\end{array}$ \\
\hline & Zhang et al. (2000) & $\begin{array}{c}\text { The tolerance feature analysis, accessibility analysis, } \\
\text { clustering algorithm, path generation and inspection } \\
\text { process simulation using CAPP systems are } \\
\text { presented. }\end{array}$ \\
\hline & $\begin{array}{l}\text { Case and Wan } \\
\text { Harun (2000) }\end{array}$ & $\begin{array}{c}\text { integrated process planning and assembly } \\
\text { information system is considered to generate new } \\
\text { CAD/CAM systems } \\
\text { that are capable of assisting in the optimization of } \\
\text { product design }\end{array}$ \\
\hline \multirow{3}{*}{$\begin{array}{l}\text { Variant Process Planning } \\
\text { systems }\end{array}$} & $\begin{array}{l}\text { Ham, Kim, and } \\
\text { Park (2017) }\end{array}$ & $\begin{array}{l}\text { Methods of evaluating and modifying assembly } \\
\text { process plans based on the variant process planning } \\
\text { systems are developed. }\end{array}$ \\
\hline & $\begin{array}{l}\text { Nau, Herrmann, } \\
\text { and Regli (2000) }\end{array}$ & $\begin{array}{l}\text { An algorithm is developed to solve the } \\
\text { maximal cutter finding problem for general } \\
\text { 2-D milling processes. }\end{array}$ \\
\hline & $\begin{array}{c}\text { Przybysz and } \\
\text { Pijanowski (2007) } \\
\end{array}$ & $\begin{array}{l}\text { An advanced variant process planning system in } \\
\text { modifying the manufacturing process is developed. }\end{array}$ \\
\hline \multirow{3}{*}{$\begin{array}{l}\text { Computer-Aided Inspection } \\
\text { Planning systems }\end{array}$} & Lee et al. (2004) & $\begin{array}{l}\text { A computer-aided inspection planning system for } \\
\text { on-machine measurement is developed. }\end{array}$ \\
\hline & $\begin{array}{l}\text { Kamrani et al. } \\
\text { (2015) }\end{array}$ & $\begin{array}{l}\text { Feature-based design approach for integrated CAD } \\
\text { and computer-aided inspection planning for efficient } \\
\text { measurement of CMMs is developed. }\end{array}$ \\
\hline & $\begin{array}{l}\text { Yang and Chen } \\
\text { (2005) }\end{array}$ & $\begin{array}{l}\text {. Inspection path generation in haptic virtual CMM is } \\
\text { developed. }\end{array}$ \\
\hline \multirow{3}{*}{$\begin{array}{l}\text { Energy efficient process } \\
\text { planning systems }\end{array}$} & $\begin{array}{l}\text { Calefati et al. } \\
\qquad(2012)\end{array}$ & $\begin{array}{l}\text { Application of developed CAPP system in increasing } \\
\text { efficiency of energy consumption for sample } \\
\text { ENEPLAN project is presented. }\end{array}$ \\
\hline & $\begin{array}{l}\text { Biel and Glock } \\
(2016)\end{array}$ & $\begin{array}{l}\text { A framework for classifying energy-efficient } \\
\text { production planning models is proposed. }\end{array}$ \\
\hline & Bunse et al. (2011) & $\begin{array}{l}\text { Energy efficient manufacturing system is developed } \\
\text { in the study. }\end{array}$ \\
\hline \multirow{3}{*}{$\begin{array}{l}\text { Virtual machining systems } \\
\text { for CAPP }\end{array}$} & Narita et al. (2000) & $\begin{array}{l}\text { A virtual machining simulation is developed to } \\
\text { analyze and optimize the cutting tool paths in virtual } \\
\text { environments. }\end{array}$ \\
\hline & $\begin{array}{l}\text { Kim and Woo } \\
\text { (2013) }\end{array}$ & $\begin{array}{l}\text { Virtual corner detection system is developed in the } \\
\text { study to modify the process planning of parts using } \\
\text { virtual machining system. }\end{array}$ \\
\hline & $\begin{array}{l}\text { Ahmad, Rahmani, } \\
\text { and D’Souza (2010) }\end{array}$ & $\begin{array}{l}\text { A systematic method for automatically selecting an } \\
\text { optimal tool sequence for } 2.5 \text {-axis pocket machining } \\
\text { is developed in the study. }\end{array}$ \\
\hline \multirow{3}{*}{$\begin{array}{l}\text { Applications of fuzzy } \\
\text { environments to process } \\
\text { planning systems }\end{array}$} & Aliev et al. (2007) & $\begin{array}{l}\text { Fuzzy-genetic approach to aggregate production- } \\
\text { distribution planning in supply chain management is } \\
\text { investigated. }\end{array}$ \\
\hline & $\begin{array}{l}\text { Mula, Peidro, and } \\
\text { Poler (2010) }\end{array}$ & $\begin{array}{c}\text { The effectiveness of a fuzzy mathematical } \\
\text { programming approach for supply chain production } \\
\text { planning with fuzzy demand is presented. }\end{array}$ \\
\hline & Leung et al. (2007) & $\begin{array}{l}\text { A robust optimization model for multi-site } \\
\text { production planning problem in an uncertain } \\
\text { environment is presented. }\end{array}$ \\
\hline $\begin{array}{c}\text { Knowledge based computer- } \\
\text { aided process planning } \\
\text { systems }\end{array}$ & $\begin{array}{l}\text { Denkena et al. } \\
\text { (2007) }\end{array}$ & $\begin{array}{c}\text { An overview of the CAPP field based on an } \\
\text { integrated approach combining technological and } \\
\text { business considerations is presented. }\end{array}$ \\
\hline
\end{tabular}


INDEPENDENT JOURNAL OF MANAGEMENT \& PRODUCTION (IJM\&P)

http://www.ijmp.jor.br

v. 12, n. 5, July-August 2021

ISSN: 2236-269X

DOI: 10.14807/ijmp.v12i5.1397

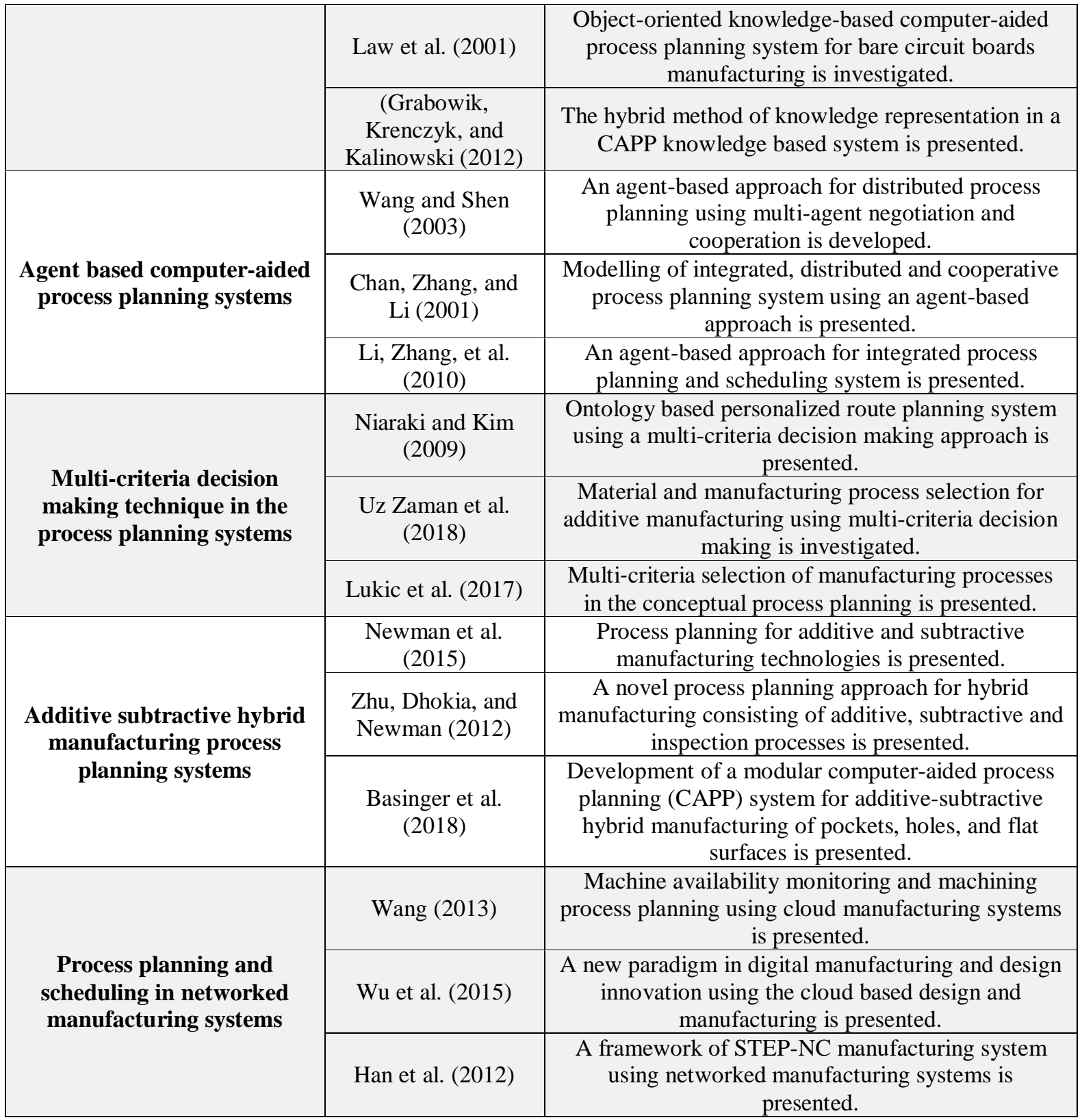

\section{CONCLUSION}

In the present research work, a review in recent development of CAPP is presented. Different topics in applications of CAPP for developing the manufacturing engineering is reviewed and discussed in order to provide a useful study for the researchers in the interesting field. Cost and time of accurate production regarding the available resources can be decreased by applying the optimization techniques to the process of part manufacturing.

To share advantages of different CAPP systems in different industry applications, artificial neural networks can be applied to the CAPP systems. Artificial Intelligence in CAPP is developed in order to use from the advanced CAPP systems in terms of efficiency enhancement of the production process. Flexible process planning systems using dynamic 
DOI: 10.14807/ijmp.v12i5.1397

CAPP and Variant Process Planning systems are developed in order to cope with product varieties in process of part production.

Computer-Aided Inspection Planning systems is presented in order to increase accuracy in process of part production. The energy consumption of part production process can be analyzed and optimized using the CAPP system in order to increase added value in the part manufacturing process. New generation of part production process can be developed by using the other knowledge of production engineering such as virtual manufacturing and simulation to the CAPP systems.

As a result, the process of part production can be modified in virtual environments without the need of shop floor testing and analysis. It is concluded that the CAPP is an advanced tool in the computer integrated manufacturing systems to increase efficiency in process of part production. Applications of fuzzy environments to process planning systems is investigated in order to increase capabilities of the current CAPP system by applying fuzzy environment to the scheduling process.

To develop the advantages of applying the knowledge objects approach in a computeraided process planning systems, Knowledge based computer-aided process planning systems is presented. To manage the interactions and communications between agents in developed CAPP systems, agent based computer-aided process planning systems is presented.

Multi-criteria decision making technique in the process planning systems is studied in different research works to tackle uncertainties in the decision making for the process planning strategies. Additive subtractive hybrid manufacturing process planning systems is presented to apply the process planning systems for additive and subtractive manufacturing technologies. Process planning and scheduling in networked manufacturing systems is studied to share advantages and capabilities of different CAPP systems using web of knowledge.

New demands of CAPP systems can be created because of increasing part complexities and manufacturing process developments. The CAPP systems can be connected by using web systems in order to share date between different applications of process planning. So, the advantages of different CAPP systems can be increased and more sophisticated parts can be considered in order to be analyzed by the CAPP systems.

Application of fuzzy logic as well as optimization methods such as genetic algorithm in process planning can be developed in order to increase ability of part production analysis. Green manufacturing systems can be developed using advanced CAPP systems in order to decrease the environmental pollutions due to manufacturing engineering. Also, waste materials 
DOI: 10.14807/ijmp.v12i5.1397

in manufacturing operations can be decreased by applying the advanced CAPP systems to the process of part production.

Applications of virtual manufacturing systems in the CAPP can be developed in order to analyze and modify the process of part production in virtual environments. The CAPP can be applied to the supply chain management systems in order to cope with product complexities in the sophisticated parts. Multi-criterion decision-making problems can be analyzed using flexible CAPP systems to manage the balancing resources. Developed assemble systems can be managed by using the CAPP to decrease time and cost of product assembly process.

The knowledge based CAPP systems can be developed in the fuzzy environments to be more effective in the part production scheduling processes. The advanced CAPP systems can be connected together via network in order to share the advantages of different CAPP systems. Web-based service-oriented systems can be applied to the different CAPP systems in order to be connected and developed. These are suggestions for the future research works in the research filed to develop the applications of CAPP systems in the part manufacturing systems.

\section{REFERENCES}

Abou-Ali, M., \& Shouman, M. (2004). Effect of dynamic and static dispatching strategies on dynamically planned and unplanned FMS. Journal of materials processing technology, 148(1), 132-8.

Agrawal, R., Shukla, S., Kumar, S., \& Tiwari, M. (2009). Multi-agent system for distributed computer-aided process planning problem in e-manufacturing environment. The

International Journal of Advanced Manufacturing Technology, 44(5-6), 579-94.

Ahmad, N., Haque, A., \& Hasin, A. (2001). Current trend in computer aided process planning. Paper presented at the Proceedings of the 7th Annual Paper Meet and 2nd International Conference

Ahmad, Z., Rahmani, K., \& D’Souza, R. M. (2010). Applications of genetic algorithms in process planning: tool sequence selection for 2.5-axis pocket machining. Journal of Intelligent Manufacturing, 21(4), 461-70.

Alam, M., Lee, K. S., Rahman, M., \& Zhang, Y. (2003). Process planning optimization for the manufacture of injection moulds using a genetic algorithm. International Journal of Computer Integrated Manufacturing, 16(3), 181-91.

Aliev, R. A., Fazlollahi, B., Guirimov, B., \& Aliev, R. R. (2007). Fuzzy-genetic approach to aggregate production-distribution planning in supply chain management. Information Sciences, 177(20), 4241-55.

Allen, R., Harding, J., \& Newman*, S. (2005). The application of STEP-NC using agentbased process planning. International journal of production research, 43(4), 655-70.

Álvares, A. J., Ferreira, J. C. E., \& Lorenzo, R. M. (2008). An integrated web-based CAD/CAPP/CAM system for the remote design and manufacture of feature-based cylindrical parts. Journal of Intelligent Manufacturing, 19(6), 643. 
Amaitik, S. M., \& Kiliç, S. E. (2007). An intelligent process planning system for prismatic parts using STEP features. The International Journal of Advanced Manufacturing Technology, 31(9-10), 978-93.

Azab, A., Perusi, G., ElMaraghy, H. A., \& Urbanic, J. (2007). Semi-generative macroprocess planning for reconfigurable manufacturing. Digital Enterprise Technology, 251-8. Springer.

Balic, J., \& Korosec, M. (2002). Intelligent tool path generation for milling of free surfaces using neural networks. International Journal of Machine Tools and Manufacture, 42(10), 1171-9.

Basinger, K. L., Keough, C. B., Webster, C. E., Wysk, R. A., Martin, T. M., \& Harrysson, O. L. (2018). Development of a modular computer-aided process planning (capp). system for additive-subtractive hybrid manufacturing of pockets, holes, and flat surfaces. The

International Journal of Advanced Manufacturing Technology, 96(5-8), 2407-20.

Biel, K., \& Glock, C. H. (2016). Systematic literature review of decision support models for energy-efficient production planning. Computers \& Industrial Engineering, 101), 243-59.

Brecher, C., Bäumler, S., \& Triebs, J. (2013). Virtual Production Systems: Simulating the Energy Consumption of Machine Tools. Future Trends in Production Engineering, 37987. Springer.

Bunse, K., Vodicka, M., Schönsleben, P., Brülhart, M., \& Ernst, F. O. (2011). Integrating energy efficiency performance in production management-gap analysis between industrial needs and scientific literature. Journal of Cleaner Production, 19(6-7), 667-79.

Calefati, P., Pandremenos, J., Fysikopoulos, A., \& Chryssolouris, G. (2012). Energy Efficient Process Planning System-The ENEPLAN Project. Paper presented at the IFIP International Conference on Advances in Production Management Systems.

Case, K., \& Wan Harun, W. (2000). Feature-based representation for manufacturing planning. International journal of production research, 38(17), 4285-300.

Chan, F., Zhang, J., Li, P. (2001). Modelling of integrated, distributed and cooperative process planning system using an agent-based approach. Proceedings of the Institution of Mechanical Engineers, Part B: Journal of Engineering Manufacture, 215(10), 1437-51.

Chang, P.-T., \& Chang, C.-H. (2000). An integrated artificial intelligent computer-aided process planning system. International Journal of Computer Integrated Manufacturing, 13(6), 483-97.

Chen, H.-C., Yau, H.-T., \& Lin, C.-C. (2012). Computer-aided process planning for NC tool path generation of complex shoe molds. The International Journal of Advanced Manufacturing Technology, 58(5-8), 607-19.

Cheok, B., Li, J., \& Nee, A. (2002). Integrated feature-based modelling and process planning of bending operations in progressive die design. The International Journal of Advanced Manufacturing Technology, 20(12), 883-95.

Cho, M.-W., Lee, H., Yoon, G.-S., \& Choi, J.-H. (2004). A computer-aided inspection planning system for on-machine measurement—part II: Local inspection planning —. KSME International Journal, 18(8), 1358-67.

Cho, M.-W., Lee, H., Yoon, G.-S., \& Choi, J. (2005). A feature-based inspection planning system for coordinate measuring machines. The International Journal of Advanced Manufacturing Technology, 26(9-10), 1078-87. 
Cho, M.-W., \& Seo, T.-I. (2002). Inspection planning strategy for the on-machine measurement process based on CAD/CAM/CAI integration. The International Journal of Advanced Manufacturing Technology, 19(8), 607-17.

Chougule, R., \& Ravi*, B. (2005). Variant process planning of castings using AHP-based nearest neighbour algorithm for case retrieval. International journal of production research, 43(6), 1255-73.

Chu, X., Tso, S., \& Tu, Y. (2000). A novel methodology for computer-aided process planning. The International Journal of Advanced Manufacturing Technology, 16(10), 714-9.

Deb, S., Ghosh, K., \& Paul, S. (2006). A neural network based methodology for machining operations selection in computer-aided process planning for rotationally symmetrical parts. Journal of Intelligent Manufacturing, 17(5), 557-69.

Denkena, B., Shpitalni, M., Kowalski, P., Molcho, G., \& Zipori, Y. (2007). Knowledge management in process planning. CIRP annals, 56(1), 175-80.

Ding, G., Zhu, S., Yahya, E., Jiang, L., Ma, S., \& Yan, K. (2014). Prediction of machining accuracy based on a geometric error model in five-axis peripheral milling process.

Proceedings of the Institution of Mechanical Engineers, Part B: Journal of Engineering Manufacture, 228(10), 1226-36.

Feng, S. C., Stouffer, K. A., \& Jurrens, K. K. (2005). Manufacturing planning and predictive process model integration using software agents. Advanced Engineering Informatics, 19(2), 135-42.

Grabowik, C., Krenczyk, D., \& Kalinowski, K. (2012). The hybrid method of knowledge representation in a CAPP knowledge based system. Paper presented at the International Conference on Hybrid Artificial Intelligence Systems.

Guo, Q.-l., \& Zhang, M. (2010). An agent-oriented approach to resolve scheduling optimization in intelligent manufacturing. Robotics and Computer-Integrated Manufacturing, 26(1), 39-45.

Ham, W. K., Kim, C. M., \& Park, S. C. (2017). Template-based variant process planning for manned assembly lines. International Journal of Computer Integrated Manufacturing, 30(9), 958-69.

Han, Z. Y., Hu, P., Han, D. D., \& Fu, H. Y. (2012). A Framework of STEP-NC Manufacturing System Integrating CAD, CAPP, CAM and CNC. Paper presented at the Applied Mechanics and Materials.

Hou, M., \& Faddis, T. (2006). Automatic tool path generation of a featurebasedCAD/CAPP/CAM integrated system. International Journal of Computer Integrated Manufacturing, 19(4), 350-8.

Isnaini, M. M. R., \& Shirase, K. (2014). Review of computer-aided process planning systems for machining operation-future development of a computer-aided process planning system-. International Journal of Automation Technology, 8(3), 317-32.

Joo, J., Park, S., \& Cho, H. (2001). Adaptive and dynamic process planning using neural networks. International journal of production research, 39(13), 2923-46.

Kamrani, A., Nasr, E. A., Al-Ahmari, A., Abdulhameed, O., \& Mian, S. H. (2015). Featurebased design approach for integrated CAD and computer-aided inspection planning. The International Journal of Advanced Manufacturing Technology, 76(9-12), 2159-83. 
Kara, S., \& Li, W. (2011). Unit process energy consumption models for material removal processes. CIRP annals, 60(1), 37-40.

Karim, M. A., \& Tiong, C. T. (2019). Development of a Simple and Affordable Computer Aided Process Planning (CAPP). Paper presented at the 2019 Advances in Science and Engineering Technology International Conferences (ASET)..

Kim, S.-H., \&Woo, Y. (2013). Determination of maximum cutter sizes for planar milling by virtual corner detection. International Journal of Precision Engineering and Manufacturing, 14(9), 1565-70.

Krishna, A. G., \&Rao, K. M. (2006). Optimisation of operations sequence in CAPP using an ant colony algorithm. The International Journal of Advanced Manufacturing Technology, 29(1-2), 159-64.

Kulkarni, P., Marsan, A., \& Dutta, D. (2000). A review of process planning techniques in layered manufacturing. Rapid Prototyping Journal, 6(1), 18-35.

Kumar, M., \& Rajotia, S. (2005). Development of a generative CAPP system for axisymmetric components for a job shop environment. The International Journal of Advanced Manufacturing Technology, 27(1-2), 136-44.

Kumar, S., \& Shanker, K., Lal, G. (2003). A generative process planning system for cold extrusion. International journal of production research, 41(2), 269-95.

Kumar, S. L. (2017). State of the art-intense review on artificial intelligence systems application in process planning and manufacturing. Engineering Applications of Artificial Intelligence, 65, 294-329.

Law, H.-W., Tam, H.-Y., Chan, A. H., \& Hui, I. (2001). Object-oriented knowledge-based computer-aided process planning system for bare circuit boards manufacturing. Computers in industry, 45(2), 137-53.

Lee, H., Cho, M.-W., Yoon, G.-S., \& Choi, J.-H. (2004). A computer-aided inspection planning system for on-machine measurement-part I: Global inspection planning-. KSME International Journal, 18(8), 1349-57.

Leung, S. C., Tsang, S. O., Ng, W.-L., \& Wu, Y. (2007). A robust optimization model for multi-site production planning problem in an uncertain environment. European Journal of Operational Research, 181(1), 224-38.

Li, L., Fuh, J., Zhang, Y., \& Nee, A. (2005). Application of genetic algorithm to computeraided process planning in distributed manufacturing environments. Robotics and ComputerIntegrated Manufacturing, 21(6), 568-78.

Li, X., Gao, L., Zhang, C., \& Shao, X. (2010). A review on integrated process planning and scheduling. International Journal of Manufacturing Research, 5(2), 161-80.

Li, X., Zhang, C., Gao, L., Li, W., \& Shao, X. (2010). An agent-based approach for integrated process planning and scheduling. Expert Systems with Applications, 37(2), 1256-64.

Lin, C.-J., \& Wu, W.-W. (2008). A causal analytical method for group decision-making under fuzzy environment. Expert Systems with Applications, 34(1), 205-13.

$\mathrm{Lu}, \mathrm{Y} ., \quad \& \mathrm{Xu}, \mathrm{X}$. (2015). Process and production planning in a cloud manufacturing environment. Paper presented at the ASME 2015 International Manufacturing Science and Engineering Conference. 
Lukic, D., Milosevic, M., Antic, A., Borojevic, S., \& Ficko, M. (2017). Multi-criteria selection of manufacturing processes in the conceptual process planning. Advances in Production Engineering \& Management, 12(2), 151.

Majstorović, V. D., Šibalija, T. V., Erčević, B. M., \& Erčević, M. M. (2013). CAPP model for prismatic parts in digital manufacturing. Paper presented at the IFIP International Conference on Digital Product and Process Development Systems.

Manafi, D., Nategh, M., \& Parvaz, H. (2017). Extracting the manufacturing information of machining features for computer-aided process planning systems. Proceedings of the Institution of Mechanical Engineers, Part B: Journal of Engineering Manufacture, 231(12), 2072-83.

Manupati, V. K., Putnik, G. D., Tiwari, M. K., Ávila, P., \& Cruz-Cunha, M. M. (2016). Integration of process planning and scheduling using mobile-agent based approach in a networked manufacturing environment. Computers \& Industrial Engineering, 94), 63-73.

Mula, J., Peidro, D., \& Poler, R. (2010). The effectiveness of a fuzzy mathematical programming approach for supply chain production planning with fuzzy demand. International Journal of Production Economics, 128(1), 136-43.

Müller, E., Poller, R., Hopf, H., \& Krones, M. (2013). Enabling energy management for planning energy-efficient factories. Procedia CIRP, 7, 622-7.

Nallakumarasamy, G., Srinivasan, P., Raja, K. V., \& Malayalamurthi, R. (2011). Optimization of operation sequencing in CAPP using simulated annealing technique (SAT). The International Journal of Advanced Manufacturing Technology, 54(5-8), 721-8.

Nallakumarasamy, G., Srinivasan, P. S. S., Raja, K. V., \& Malayalamurthi, R. (2011). Optimization of operation sequencing in CAPP using superhybrid genetic algorithmssimulated annealing technique. ISRN Mechanical Engineering, 2011, 1-7.

Naranje, V., \&Kumar, S. (2014). A knowledge based system for automated design of deep drawing die for axisymmetric parts. Expert Systems with Applications, 41(4), 1419-31.

Narita, H., Shirase, K., Wakamatsu, H., \& Arai, E. (2000). Pre-process evaluation of end milling operation using virtual machining simulator. JSME International Journal Series C Mechanical Systems, Machine Elements and Manufacturing, 43(2), 492-7.

Nassehi, A., Newman, S., \& Allen, R. (2006). The application of multi-agent systems for STEP-NC computer aided process planning of prismatic components. International Journal of Machine Tools and Manufacture, 46(5), 559-74.

Nau, D. S., Herrmann, J. W., \& Regli, W. C. (2000). Design Classification and Hybrid Variant-Generative Process Planning. Paper presented at the NSF Design and Manufacturing Research Conference.

Neugebauer, R., Hochmuth, C., Schmidt, G., \& Dix, M. (2011). Energy efficient process planning based on numerical simulations. Paper presented at the Advanced Materials Research.

Newman, S. T., Zhu, Z., Dhokia, V., \& Shokrani, A. (2015). Process planning for additive and subtractive manufacturing technologies. CIRP annals, 64(1), 467-70.

Niaraki, A. S., \& Kim, K. (2009). Ontology based personalized route planning system using a multi-criteria decision making approach. Expert Systems with Applications, 36(2), 2250-9.

Niebel, B. W. (1967). Motion and time study. v. 1: RD Irwin. 
Ong, T., \& Hinds, B. (2003). The application of tool deflection knowledge in process planning to meet geometric tolerances. International Journal of Machine Tools and Manufacture, 43(7), 731-7.

Paris, H., \& Mandil, G. (2017). Process planning for combined additive and subtractive manufacturing technologies in a remanufacturing context. Journal of Manufacturing Systems, 44, 243-54.

Park, S. C. (2003). Knowledge capturing methodology in process planning. ComputerAided Design, 35(12), 1109-17.

Patil, L., \& Pande, S. (2002). An intelligent feature-based process planning system for prismatic parts. International journal of production research, 40(17), 4431-47.

Peidro, D., Mula, J., Jiménez, M., \& del Mar Botella, M. (2010). A fuzzy linear programming based approach for tactical supply chain planning in an uncertainty environment. European Journal of Operational Research, 205(1), 65-80.

Peidro, D., Mula, J., Poler, R., \& Verdegay, J.-L. (2009). Fuzzy optimization for supply chain planning under supply, demand and process uncertainties. Fuzzy sets and systems, 160(18), 2640-57.

Phanden, R. K., Jain, A., \& Verma, R. (2011). Integration of process planning and scheduling: a state-of-the-art review. International Journal of Computer Integrated Manufacturing, 24(6), 517-34.

Pohekar, S., \& Ramachandran, M. (2004). Application of multi-criteria decision making to sustainable energy planning-A review. Renewable and sustainable energy reviews, 8(4), 365-81.

Prakash, A., Chan, F., \& Deshmukh, S. (2012). Application of knowledge-based artificial immune system (KBAIS). for computer aided process planning in CIM context.

International journal of production research, 50(18), 4937-54.

Przybysz, E., \& Pijanowski, M. (2007). Some aspects of variant computer aided process planning systems. In.: Poznan University of Technology, Poznan, Poland.

Rojek, I. (2017). Technological process planning by the use of neural networks. AI EDAM, 31(1), 1-15.

S. Pande, S., \& Kumar, S. (2008). A generative process planning system for parts produced by rapid prototyping. International journal of production research, 46(22), 6431-60.

Sadaiah, M., Yadav, D., Mohanram, P., \& Radhakrishnan, P. (2002). A generative computeraided process planning system for prismatic components. The International Journal of Advanced Manufacturing Technology, 20(10), 709-19.

Salehi, M., \& Tavakkoli-Moghaddam, R. (2009). Application of genetic algorithm to computer-aided process planning in preliminary and detailed planning. Engineering Applications of Artificial Intelligence, 22(8), 1179-87.

Sasaki, Y., Sonda, M., \& Ito, K. (2003). Development of a computer-aided process planning system based on a knowledge base. Journal of marine science and technology, 7(4), 175-9.

Saygin, C., \& Kilic, S. (1999). Integrating flexible process plans with scheduling in flexible manufacturing systems. The International Journal of Advanced Manufacturing

Technology, 15(4), 268-80. 
Shao, X., Li, X., Gao, L., \& Zhang, C. (2009). Integration of process planning and scheduling - a modified genetic algorithm-based approach. Computers \& Operations Research, 36(6), 2082-96.

Shen, W., Wang, L., \& Hao, Q. (2006). Agent-based distributed manufacturing process planning and scheduling: a state-of-the-art survey. IEEE Transactions on Systems, Man, and Cybernetics, Part C (Applications and Reviews), 36(4), 563-77.

Siva Sankar, R., Asokan, P., Prabhaharan, G., \& Phani, A. (2008). A CAPP framework with optimized process parameters for rotational components. International journal of production research, 46(20), 5561-87.

Soori, M., Arezoo, B., \& Habibi, M. (2013). Dimensional and geometrical errors of three-axis CNC milling machines in a virtual machining system. Computer-Aided Design, 45(11), 1306-13.

Soori, M., Arezoo, B., \& Habibi, M. (2014). Virtual machining considering dimensional, geometrical and tool deflection errors in three-axis CNC milling machines. Journal of Manufacturing Systems, 33(4), 498-507.

Soori, M., Arezoo, B., \& Habibi, M. (2016). Tool deflection error of three-axis computer numerical control milling machines, monitoring and minimizing by a virtual machining system. Journal of Manufacturing Science and Engineering, 138(8), 081005.

Soori, M., Arezoo, B., \& Habibi, M. (2017). Accuracy analysis of tool deflection error modelling in prediction of milled surfaces by a virtual machining system. International Journal of Computer Applications in Technology, 55(4), 308-21.

Sormaz, D. N., Arumugam, J., \& Ganduri, C. (2007). Integration of rule-based process selection with virtual machining for distributed manufacturing planning. In Process Planning and Scheduling for Distributed Manufacturing, 61-90. Springer.

Stryczek, R. (2007). Computational intelligence in computer aided process planning-a review. Advances in manufacturing science and technology, 31(4), 77-92.

Sun, W., \& Lal, P. (2002). Recent development on computer aided tissue engineering-a review. Computer methods and programs in biomedicine, 67(2), 85-103.

Tan, W., \& Khoshnevis, B. (2000). Integration of process planning and scheduling-a review. Journal of Intelligent Manufacturing, 11(1), 51-63.

Tiwari, M., Kotaiah, K. R., \& Bhatnagar, S. (2001). A case-based computer-aided processplanning system for machining prismatic components. The International Journal of Advanced Manufacturing Technology, 17(6), 400-11.

Uz Zaman, U. K., Rivette, M., Siadat, A., \& Mousavi, S. M. (2018). Integrated productprocess design: Material and manufacturing process selection for additive manufacturing using multi-criteria decision making. Robotics and Computer-Integrated Manufacturing, 51), 169-80.

Wang, A., Koc, B., \& Nagi, R. (2005). Complex assembly variant design in agile manufacturing. Part I: system architecture and assembly modeling methodology. IIE Transactions, 37(1), 1-15.

Wang, J., Zhang, H. L., \& Su, Z. Y. (2012). Manufacturing knowledge modeling based on artificial neural network for intelligent CAPP. Paper presented at the Applied Mechanics and Materials. 
Wang, L. (2013). Machine availability monitoring and machining process planning towards Cloud manufacturing. CIRP Journal of Manufacturing Science and Technology, 6(4), 263-73.

Wang, L., Keshavarzmanesh, S., Feng, H.-Y., \& Buchal, R. O. (2009). Assembly process planning and its future in collaborative manufacturing: a review. The International Journal of Advanced Manufacturing Technology, 41(1-2), 132.

Wang, L., \& Shen, W. (2003). DPP: An agent-based approach for distributed process planning. Journal of Intelligent Manufacturing, 14(5), 429-39.

Wang, Z., Chen, Y., \& Wang, N. (2004). Research on dynamic process planning system considering decision about machines. Paper presented at the Fifth World Congress on Intelligent Control and Automation (IEEE Cat. No. 04EX788)..

Weinert, N., Chiotellis, S., \& Seliger, G. (2011). Methodology for planning and operating energy-efficient production systems. CIRP annals, 60(1), 41-4.

Wong, T., Leung, C., Mak, K.-L., \& Fung, R. Y. (2006). Dynamic shopfloor scheduling in multi-agent manufacturing systems. Expert Systems with Applications, 31(3), 486-94.

Wu, D., Rosen, D. W., Wang, L., \& Schaefer, D. (2015). Cloud-based design and manufacturing: A new paradigm in digital manufacturing and design innovation. ComputerAided Design, 59, 1-14.

Xu, X., Wang, L., \& Newman, S. T. (2011). Computer-aided process planning-A critical review of recent developments and future trends. International Journal of Computer Integrated Manufacturing, 24(1), 1-31.

Yahia, N., Fnaiech, F., Abid, S., \& Sassi, B. (2002). Manufacturing process planning application using artificial neural networks. Paper presented at the IEEE International Conference on Systems, Man and Cybernetics.

Yang, Z., \& Chen, Y. (2005). Inspection path generation in haptic virtual CMM. ComputerAided Design and Applications, 2(1-4), 273-82.

You, C.-F., \& Tsai, Y.-L. (2010). 3D solid model retrieval for engineering reuse based on local feature correspondence. The International Journal of Advanced Manufacturing Technology, 46(5-8), 649-61.

Yuen, C., Wong, S., \& Venuvinod, P. K. (2003). Development of a generic computer-aided process planning support system. Journal of materials processing technology, 139(1-3), 394-401.

Yusof, Y., \& Latif, K. (2014). Survey on computer-aided process planning. The International Journal of Advanced Manufacturing Technology, 75(1-4), 77-89.

Zhang, S., Ajmal, A., Wootton, J., \& Chisholm, A. (2000). A feature-based inspection process planning system for co-ordinate measuring machine (CMM).. Journal of materials processing technology, 107(1-3), 111-8.

Zhang, W., \& Xie, S. (2007). Agent technology for collaborative process planning: a review. The International Journal of Advanced Manufacturing Technology, 32(3-4), 315-25.

Zhao, F., Xu, X., \& Xie, S. Q. (2009). Computer-aided inspection planning-the state of the art. Computers in industry, 60(7), 453-66.

Zhou, X., Qiu, Y., Hua, G., Wang, H., \& Ruan, X. (2007). A feasible approach to the integration of CAD and CAPP. Computer-Aided Design, 39(4), 324-38. 
Zhu, Z., Dhokia, V., \& Newman, S. (2012). A novel process planning approach for hybrid manufacturing consisting of additive, subtractive and inspection processes. Paper presented at the 2012 IEEE International Conference on Industrial Engineering and Engineering Management. 